\title{
PENGARUH KUALITAS PELAYANAN DAN STORE ATMOSPHERE TERHADAP KEPUASAN PELANGGAN KFC
}

\author{
M.A.R. Satrya ${ }^{1}$, N.L.W.S. Telagawathi ${ }^{2}$ \\ 1,2 Jurusan Manajemen, Universitas Pendidikan Ganesha, Singaraja \\ e-mail: anggixsatrya@gmail.com ${ }^{1}$, gemilangsuryawan@gmail.com²
}

\begin{abstract}
Abstrak
Penelitian ini bertujuan untuk menguji bagaimana pengaruh dari kualitas layanan dan store atmosphere baik secara simultan maupun secara parsial terhadap kepuasan pelanggan KFC pada pelanggan KFC Singaraja. Penelitian ini menggunakan rancangan kuantiatif kausal, dengan memilih pelanggan KFC Singaraja sebagai subjek dan kualitas pelayanan, store atmosphere serta kepuasan pelanggan sebagai objek penelitian. Sampel penelitian ditentukan dengan metode purposive sampling untuk mendapatkan sampel sebanyak 105. Data dalam penelitian ini dikumpulkan dengan menggunakan kuesioner yang selanjutnya akan dianalisis menggunakan analisis regresi linier berganda. Hasil dalam penelitian ini adalah (1) Kualitas pelayanan dan store atmosphere secara bersama-sama memberikan pengaruh signifikan ke kepuasan pelanggan KFC. (2) Kualitas pelayanan secara parsial memberikan pengaruh positif dan signifikan ke kepuasan pelanggan KFC. (3) Store atmosphere secara parsial memberikan pengaruh positif dan signifikan ke kepuasan pelanggan KFC.
\end{abstract}

Kata kunci: kepuasan pelanggan, kualitas pelayanan, store atmosphere

\begin{abstract}
This study animed to examine the effect of simultaneous and partially service quality and store atmosphere on costumers satisfaction KFC Singaraja. The research design of this research used casual quantitative research. The subject of this research is the customers of KFC Singaraja, and the object of this research is the service quality, store atmosphere and customers satisfaction. The sample collection technique uses in this research is purposive sampling. The sample of this research involved 105 respondents. The instrument used in data collection was a questionnaire and the data analysis technique used was multiple liniear regression analysis. The result of this research indicate that (1) service quality and store atmosphere have a significant effect on costumer satisfaction. (2) service quality has positive and significant effect on costumers satisfaction. (3) store atmosphere has positive and significant effect on costumers satisfaction.
\end{abstract}

Keywords : costumers satisfaction, service quality, store atmosphere

\section{Pendahuluan}

Makanan dan minuman merupakan salah satu kebutuhan yang wajib dipenuhi semua orang. Seiring meningkatnya populasi pertumbuhan manusia maka semakin banyak pula diperlukannya kebutuhan pokok seperti makanan dan minuman. Melihat kondisi seperti ini tentunya makanan dan minuman merupakan potensi bisnis yang sangat menjanjikan. Perkembangan bisnis makanan dan minuman yang terus meningkat juga dapat dilihat dengan seiring bertambahnya jumlah restoran/rumah makan. Pada tahun 2019 di provinsi Bali terdapat 2.864 restoran atau rumah makan yang tersebar diberbagai daerah di Bali (BPS, 2019).

Meningkatnya mobilitas masyarakat dan aktivitas kerja yang sibuk juga salah satu penyabab perubahan perilaku masyarakat yang dulunya memasak kini beralih untuk membeli makanan jadi untuk memenuhi kebutuhannya. Hal tersebut juga tidak menutup kemungkinan menyebabkan jumlah restoran terus meningkat setiap tahunnya. Salah satu jenis restoran yang mengalami perkembangan adalah restoran cepat saji atau fast food. Restoran fast food merupakan rumah makan yang menghidangkan makanan dalam waktu yang relatif singkat. Penyajian makanan yang cepat tersebutlah yang menjadi keunggulan dari restoran cepat saji sehingga konsumen tidak harus menunggu lama untuk dapat menikmati makanannya. Fast food menjadi semakin populer karena dipercaya mampu memenuhi kebutuhan konsumsi 
masyarakat yang memiliki waktu terbatas karena kesibukan dalam pekerjaannya (Mufidah, 2012).

Sebagian besar masyarakat Indonesia lebih memilih untuk mengunjungi gerai restoran fast food dibandingkan dengan jenis rumah makan lainnya ketika hendak mencari makan di luar rumah. Menurut survei yang dilakukan oleh MasterCard dengan tema Consumer Purchasing Priorities, menyatakan $80 \%$ masyarakat Indonesia memutuskan untuk mengisi perut mereka pada gerai restoran fast food, disusul oleh pusat jajanan/food court pada posisi kedua sebanyak $61 \%$, kemudian kafe kelas menengah sebanyak $22 \%$, dan hanya sekitar $1 \%$ orang Indonesia yang memutuskan berkunjung ke restoran kelas atas untuk jamuan makan resmi atau fine dinning.

Restoran fast food yang hadir di Indonesia pertama adalah KFC yang membuka gerai pertamanya pada tahun 1979 di Jakarta (Kompas,2020). KFC adalah sebuah perusahaan bisnis waralaba yang berasal dari Amerika yang oleh Harland Sanders di tahun 1930 . Pemilik waralaba KFC di Indonesia adalah PT Fast Food Indonesia. Berdasarkan laporan tahunan KFC Indonesia tahun 2019, saat ini KFC memiliki 748 gerai yang terdapat di 169 Kota/Kabupaten di Indonesia dan di Provinsi Bali saat ini KFC memiliki 25 gerai yang tersebar diberbagai wilayah di Bali. Pada tahun 2017-2019 KFC selalu mengalami peningkatan penjualan seiring dengan meningkatnya jumlah gerai baru KFC. Dimana pada tahun 2017 penjualan KFC mencapai Rp.5,3 Triliun atau meningkat 8,59\% dengan jumlah gerai sebanyak 628 gerai. Kemudian pada tahun 2018 penjualan KFC Indonesia mencapai Rp.6,02 Triliun atau meningkat sebesar $13,48 \%$ dengan jumlah gerai sebanyak 689 gerai. Tahun 2019 penjualan KFC mencapai 6,71 Triliun atau meningkat $11,45 \%$ dengan jumlah gerai sebanyak 748 gerai.

Sebagai sebuah perusahaan yang beregak dibidang makanan cepat saji, KFC tentunya memiki banyak pesaing dalam usahanya tersebut. Di Provinsi Bali sendiri sudah terdapat berbagai jenis restoran cepat saji modern sejenis seperti McDonald's, A\&W, CFC, Richeese Factory, BurgerKing, Hoka-Hoka Bento, dan lain sebagainya. Kompetitor tersebut sama-sama memiliki produk unggulan ayam goreng dan juga sudah dikenali oleh masyarakat secara luas. Dengan meningkatnya pelaku bisnis waralaba makanan cepat saji menyebabkan persaingan dalam industri tersebut menjadi semakin kompetitif. Persaingan tersebut tentunya menjadi suatu tantangan tersendiri bagi KFC dan perusahaan lainnya untuk menyiapkan berbagai strategi agar dapat unggul dan memenangkan pasar.

Berdasarkan data pada Top Brand Index menyatakan bahwa KFC selalu menjadi Top Brand dengan berada diperingkat pertama sejak tahun 2017 hingga tahun 2019, dengan persentase $60.4 \%$ di tahun 2017 kemudian menurun menjadi $42.7 \%$ di tahun 2018 dan turun lagi menjadi $26.2 \%$ di tahun 2019 . Berlandaskan data yang bersumber dari top brand index dapat dilihat KFC menjadi penguasa pasar fast food di Indonesia dengan berada di peringkat satu. Kemudian disusul oleh McDonald's dan pesaing lainnya. Dalam tabel tersebut juga terlihat KFC memang masih menjadi peringkat pertama sebagai Top Brand fast food di Indonesia, namun perlu dilihat juga bahwa index persentase dari KFC tersebut selalu mengalami penurunan setiap tahunnya. Berbeda dengan pesaing lainnya yang mengalami fluktuasi dan cenderung meningkat di tahun 2018 dan mengalami sedikit penurunan di tahun 2019. Sedangkan KFC yang mengalami penurunan sebesar $17.7 \%$ di tahun 2018 dan kembali turun sebesar $16.5 \%$ di tahun 2019. Kondisi tersebut apabila terus dibiarkan dapat menggeser posisi puncak KFC sebagai Top Brand fast food di Indonesia.

Untuk tetap berada diposisi puncak dan memenangkan persaingan KFC tentunya harus menyiapkan strategi yang tepat untuk dapat memenuhi harapan konsumennya, sehingga konsumennya akan merasa puas ketika membeli produk dari KFC. Menurut Mulyanto dan Yoestini (2011), Kepuasan pelanggan mampu meningkatkan pertumbuhan konsumen serta dapat memberikan hasil yang positif bagi perusahaan. Kepuasan pelanggan merupakan suatu bentuk proses evaluasi setelah melakukan pembelian, jika pelanggan merasa puas tentunya dapat menimbulkan loyalitas pada pelanggan, sebab itu kepuasan pelanggan menjadi suatu yang sangat penting untuk suatu usaha (Sulistyawati \& Seminari, 2015). Seorang pelanggan yang terpuaskan oleh suatu produk yang digunakan umumnya akan menjadi pelanggan dan akan terus menerus membeli serta menggunakan produk tersebut. 
Hal itu juga memungkinkan pelanggan untuk menceritakan tentang pengalamannya terhadap suatu produk yang telah digunakan kepada orang lain.

Dalam memperoleh kepuasan pelanggan dapat dilakukan dengan cara memberikan kualitas pelayanan yang maksimal. Kualitas pelayanan menjadi suatu hal yang tidak dapat dilepaskan dengan kepuasan pelanggan, karena kualitas pelayanan dapat memotivasi pelanggan untuk menumpuk ikatan yang kuat dengan suatu usaha, dan untuk kedepannya ikatan seperti ini memungkinkan suatu usaha secara cermat untuk menafsirkan harapan serta apa yang menjadi keperluan bagi pelanggan (Dewi,dkk, 2019). Ketika sebuah perusahaan memberikan suatu pelayanan yang tidak menyenangkan akan menyebabkan pelanggan tidak puas dan berpindah kepada produk lain. Oleh sebab itulah kualitas pelayanan itu tidak boleh dikesampingkan dalam sebuah usaha, karena akan berdampak kepada keunggulan kompetitif suatu perusahaan. Pelayanan yang maksimal akan mampu memenuhi harapan pelanggan dan menyebabkan semakin tingginya kepuasan pelanggan (Lutfi, 2020). Sesuai hasil riset Sulistyawati dan Seminari (2015) mengungkapkan bahwa variabel kualitas pelayanan memberikan pengaruh positif dan signifikan ke kepuasan pelanggan. Hal yang sama juga diperoleh Nawangsih (2017) yang menyatakan kualitas pelayanan mempunyai pengaruh positif dan signifikan ke kepuasan pelanggan. Penelitian oleh Kusumawathi,dkk (2019) juga menjelaskan kualitas pelayanan memberikan pengaruh yang signifikan dan memiliki nilai positif ke kepuasan konsumen. Namun hal berbeda terdapat pada riset yang dilakukan Tresiya,dkk (2018) yang menyatakan jika kualitas pelayanan tidak mempunyai pengaruh ke kepuasan pelanggan. Hal tersebut juga dikemukakan oleh Dewi,dkk (2019) menunjukan bahwa dalam pengujian dimensi kualitas pelayanan didapat dimensi kompetensi, mengakses, sikap sopan dan santun, komunikasi serta keamanan tidak memiliki dampak yang signifikan ke kepuasaan pelanggan.

KFC sebagai sebuah restoran fast food modern tentunya harus memiliki suasana toko atau store atmosphere yang terencana. Menurut Kotler dan Keller (2009) setiap gerai harus memiliki atmosfer yang terencana dan sesuai dengan target pasarnya sehingga mampu mempengaruhi pelanggan ketika melakukan pembelian. Dengan store atmosphere yang menarik tentunya akan memberikan kesan yang nyaman pada pelanggan. Konsumen tidak hanya menanggapi suatu produk yang disediakan, akan tetapi konsumen juga memberikan tanggapan pada susana pembelian yang mampu memberikan perasaan menyenangkan menurut konsumen (Putri,dkk, 2014). Sejalan dengan hasil riset dari Kusumawathi,dkk (2019) yang menyatakan store atmosphere memberikan dampak yang positif dan signifikan ke kepuasan konsumen. Penelitian yang dilakukan Kristiana dan Edwar (2017) juga memperoleh hasil store atmosphere memberikan pengaruh ke kepuasan pelanggan. Hal yang sama juga didapat dari penelitian Nawangsih (2017) yang menunjukan variabel store atmosphere terbukti memberikan pengaruh yang signifikan dan positif ke kepuasan pelanggan. Namun hal berbeda terjadi pada penelitian yang dilaksanakan oleh Pojoh,dkk (2019) yang menyatakan suasana toko tidak memberikan dampak signifikan ke kepuasan pelanggan. Dalam penelitian Putri,dkk (2014) juga menemukan hasil jika store atmosphere tidak memberikan dampak yang signifikan ke kepuasan pelanggan.

Menciptakan kepuasan pelanggan adalah hal yang wajib dilakukan oleh perusahaan, karena kepuasan pelanggan merupakan upaya pemenuhan kebutuhan dan keinganan pelanggan. Tjiptono (2011) yang menyatakan kualitas pelayanan dan kepuasan pelanggan adalah dua hal yang tidak bisa dipisahkan karena kualitas pelayanan yang baik mampu memotivasi pelanggan untuk menjalin ikatan kuat dengan suatu usaha. Ketika suatu layanan yang diberi sesuai dengan yang diharapkan pelanggan tentunya dapat memberi perasaan senang dan dapat memberikan respon positif kepada perusahaan tersebut. Untuk dapat memenuhi kebutuhan dan keinginan pelanggan, perlu adanya pelayanan yang optimal serta suasana gerai yang terencana dengan baik sehingga memberikan kenyamanan dan rasa puas terhadap pelanggan. Sejalan dengan penelitian Kristiana dan Edwar (2017), Nawaningsih (2017) dan Kusumawathi,dkk (2019) yang mendatkan hasil store atmosphere dan kualitas layanan mempunyai dampak secara parsial dan simultan ke kepuasan pelanggan. $\mathrm{H} 1$ : Terdapat pengaruh kualitas pelayanan dan store atmosphere terhadap kepuasan pelanggan 
Kualitas layanan memiliki peran penting untuk membangun kepuasan pada pelanggan. Sebuah perusahaan yang menyediakan pelayanan yang maksimal akan menimbulkan rasa kepuasan terhadap pelanggan sehingga kembali membeli barang atau jasa pada suatu usaha. Hal tersebut juga sejalan dengan riset Sulistyawati dan Seminari (2015) bahwa variabel kualitas pelayanan memberi dampak positif dan signifikan ke kepuasan pelanggan. Hal yang sama diperoleh dari riset Nawangsih (2017) yaitu kualitas pelayanan mempengaruhi secara positif signifikan ke kepuasan pelanggan. Penelitian Kusumawathi,dkk (2019) juga mendapatkan hasil jika kualitas pelayanan memberi pengaruh positif signifikan ke kepuasan pelanggan. H2: Terdapat pengaruh antara kualitas pelayanan terhadap kepuasan pelanggan.

Store atmosphere menjadi suatu hal penting dalam menentukan kepuasan pelanggan. Dengan store atmosphere yang menarik tentunya akan memberikan kesan yang nyaman pada pelanggan. Semakin baik suasana yang mampu diciptakan oleh gerai maka hal tersebut akan memberi pengaruh pada lingkungan belanja konsumen. Sejalan dengan hasil penelitian Kusumawathi,dkk (2019) yang menyatakan store atmosphere memberi pengaruh positif dan signifikan ke kepuasan konsumen. Riset sebelumnya yang dilaksanakan Kristiana dan Edwar (2017) juga menyatakan bahwa store atmosphere berpengaruh ke kepuasan pelanggan. Hal yang sama juga didapat dari penelitian Nawangsih (2017) yang memperoleh hasil jika variabel store atmosphere terbukti memberi pengaruh positif signifikan ke kepuasan pelanggan. H3: Terdapat pengaruh antara store atmosphere terhadap kepuasan pelanggan.

Sebagaimana diuaraikan sebelumnya, penelitian ini memilih KFC sebagai subjek penelitian karena berdasarkan data top brand index dalam tiga tahun terakhir yang menunjukan adanya persaingan kompetitif antara KFC dengan para pesaingnya. Dimana KFC masih menempati peringkat pertama daftar Top Brand Index tetapi persentase indexnya terus mengalami penurunan. Berbeda dengan pesaingnya yang terus mengalami fluktuasi dan cenderung meningkat. Berdasarkan adanya ketidakkonsistenan hasil penelitian dan teori yang dikemukan oleh para ahli maka diperlukan analisis lebih mendalam mengenai pengaruh kualitas pelayanan dan store atmosphere terhadap kepuasan pelanggan. Adapun tujuan penelitian yaitu menguji (1) Pengaruh kualitas pelayanan dan store atmosphere terhadap kepuasan pelanggan KFC. (2) Pengaruh kualitas pelayanan terhadap kepuasan pelanggan KFC. (3) Pengaruh store atmosphere terhadap kepuasan pelanggan KFC.

\section{Metode}

Penelitian ini menggunakan desain penelitian kuantitatif kausal yang digunakan untuk menganalisis hubungan sebab akibat antar variabel bebas dengan variabel terikat (Sugiyono, 2014:56). Penelitian ini menggunakan analisis regresi linier berganda untuk menguji pengaruh kualitas pelayanan dan store atmosphere ke kepuasan pelanggan.

Dalam riset ini memakai kualitas pelayanan dan store atmosphere sebagai variabel bebas dan variabel terikat yaitu kepuasan pelanggan. Penelitian ini memakai pelanggan KFC di Kota Singaraja yang sudah pernah melakukan pembelian lebih dari dua kali produk KFC sebagai subjek penelitian, sedangkan objek yang digunakan adalah kualitas pelayanan (X1), store atmosphere (X2), dan kepuasan pelanggan (Y). Sampel penelitian berjumlah 105 responden yang ditentukan dengan teknik purposive sampling, yang artinya penentuan sampel dipilih atas pertimbangan atau kreteria tertentu yang ditetapkan peneliti (Sugiyono, 2017). Adapun data yang didapatkan dikumpulkan melalui kuesioner yang selanjutnya akan di uji melalui uji validitas dan uji reliabilitas.

\section{Hasil dan Pembahasan}

Hasil uji validitas dapat dijelaskan melalui perbandingan antara nilai $p$-value yang memiliki angka lebih tinggi dari nilai alpha ( $\alpha$ ) 0,05. Berdasarkan hasil output SPSS diketahui bahwa seluruh item pernyataan memiliki nilai $p$-value di atas 0,05 , sehingga bisa dikatakan item kuesioner dalam penelitian tersebut valid. Selanjutnya pengujian reliabilitas tersebut terkait dengan masalah adanya kepercayaan pada instrumen penelitian. Untuk mengetahui reliabel tidaknya suatu data diuji maka harus diuji reliabitasnya terlebih dahulu. Suatu variabel dikatakan reliabel ketika mempunyai nilai croncbach alpha diatas 0.60 . Berdasarkan hasil uji reliabilitas diketahui bahwa semua variabel yang diuji reliabel karena memiliki nilai cronbach 
alpha diatas 0,6. Sehingga dapat disimpulkan bahwa semua instrumen variabel kualitas pelayanan, store atmosphere dan kepuasan pelanggan adalah valid dan reliabel.

Pengujian asumsi klasik yang pertama yaitu uji normalitas. Menurut Santoso (2001) ketentuannya uji normalitas dapat dilihat melalui grafik p-plot dengan ketentuan jika data menyebar disekitar garis diagonal serta mengikuti arah garis diagonal, maka dapat dikatakan model regresi memenuhi asumsi normalitas. Berdasarkan hasil pengujian yang dibantu dengan program SPSS, grafik histogram p-plot menunjukkan bahwa titik-titik yang ada berada disekitar garis diagonal. Dengan demikian dapat dikatakan jika model regresi tersebut berdistribusi normal.

Uji asumsi klasik selanjutnya yaitu uji multikolinearitas. Pengujian ini bertujuan mengetahui ada tidaknya korelasi antar variabel bebas dalam persamaan regresi. Cara untuk mengetahui multikolinieritas tersebut dapat dilihat melalui nilai tolerance yang lebih dari 0,10 dan nilai VIF kurang dari 10. Bedasarkan hasil uji multikolinieritas pada yang dibantu program SPSS, dapat disimpulkan bahwa tidak terjadi multikolinieritas antar variabel bebasnya. Hal itu dilihat dari nilai Tolerance setiap variabel bebas yaitu 0,628 yang artinya lebih besar dari $(>)$ 0,10 sedangkan nilai VIF setiap variabel bebas yaitu sebesar 1,593 yang lebih kecil dari $(<)$ 10. Maka dari analisis tersebut kesimpulannya adalah tidak terjadi multikolonieritas antar variabel bebas pada model regresi penelitian ini.

Pengujian asumsi klasik ketiga yaitu uji heteroskedastisitas. Pengujian ini digunakan untuk mengetahui apakah terdapat perbedaan variance dari residual satu pengaman pada pengamatan lain dalam model regresi penelitian ini. Untuk mengetahui terjadi tidaknya heteroskedastisitas dapat dilihat melalui grafik scatterplots, dengan ketentuan titik menyebar dibawah dan diatas angka 0 pada sumbu $Y$ dan tidak membentuk suatu pola yang jelas maka dapat disimpulkan tidak terjadi heteroskedastisitas. Berdasarkan Uji Heteroskedastisitas pada penelitian dapat dilihat jika titik-titik tidak membentuk pola dan tersebar secara acak diatas dan dibawah angka 0 pada sumbu $\mathrm{Y}$. Maka, kesimpulannya adalah tidak terjadi heteroskedastisitas pada model regresi penelitian ini.

Penelitian ini menggunakan analisis regresi berganda karena penelitian ini menggunakan lebih dari satu variabel bebas sehingga tidak bisa menggunakan regresi sederhana. Untuk mengolah data penelitian dibantu dengan program SPSS 26 for Windows, yang digunakan untuk mengetahui apakah terdapat pengaruh variabel kualitas pelayanan dan store atmosphere ke variabel kepuasan pelanggan. Sehingga mendapatkan hasil pengujian berupa ringkuman hasil output SPSS yang nampak pada Tabel 1 Berikut.

Tabel 1. Ringkasan Output SPSS Analisis Regresi Linier Berganda

\begin{tabular}{lcccc}
\hline Variabel Bebas & Koefisien & Sig & $\begin{array}{c}\text { Koefisien } \\
\text { Korelasi }\end{array}$ & $\mathrm{R}^{2}$ \\
Kualitas Pelayanan & 0,265 & 0,004 & 0,278 & 0,077 \\
Store Atmosphere & 0,379 & 0,000 & 0,377 & 0,142 \\
\hline Konstanta & 3.162 & & & \\
Sig. F & 0,000 & & & \\
$\mathrm{R}$ & 0,621 & & & \\
$\mathrm{R}^{2}$ & 0,385 & & & \\
\hline
\end{tabular}

Sumber: pengolah data pada SPSS

Berlandaskan pada hasil uji statistik analisis regresi berganda dalam Tabel 1,dimana mendapatkan nilai konstanta $(a)$ sebesar 3.162. Nilai koefisien regresi kualitas pelayanan $\left(\beta_{1}\right)$ sebesar 0,265 dan nilai koefisien regresi store atmosphere $\left(\beta_{2}\right)$ sebesar 0,379 . Berdasarkan persamaan linier berganda tersebut menunjukan bahwa: (1) Konstanta sebesar 3.162 mempunyai makna jikalau kualitas pelayanan $\left(\mathrm{X}_{1}\right)$ dan Store Atmosphere $\left(\mathrm{X}_{2}\right)$, nilainya sama dengan nol, maka kepuasan pelanggan $(Y)$ sebesar 3.162. (2) Nilai koefesien kualitas pelayanan $\left(b_{1}\right)$ sebesar 0.265 berarti kualitas pelayanan mempunyai pengaruh positif terhadap kepuasan pelanggan (Y). Hal ini mengandung arti bahwa setiap kenaikan kualitas pelayanan sebesar satu satuan maka variabel kepuasan pelanggan akan meningkat sebesar 0.265 , 
dengan asumsi bahwa variabel bebas yang lainnya tetap. (3) Nilai koefesien store atmosphere $\left(b_{2}\right)$ sebesar 0.379 berarti store atmosphere mempunyai pengaruh positif terhadap kepuasan pelanggan $(\mathrm{Y})$. Hal ini mengandung arti bahwa setiap kenaikan store atmosphere sebesar satu satuan maka variabel kepuasan pelanggan meningkat sebesar 0.379 , dengan asumsi bahwa variabel bebas yang lainnya tetap.

Hipotesis penelitian pertama adalah ada pengaruh antara kualitas pelayanan dan store atmosphere terhadap kepuasan pelanggan. Berdasarkan rekapan hasil uji regresi yang nampak di Tabel 1 menunjukan nilai koefesien korelasi antara kualitas pelayanan dan store atmosphere sebesar 0,621 dan $p$-value 0,000 < Alpha $(\alpha) 0,05$, yang menyatakan bahwa menolak Ho yang artinya kualitas pelayanan $\left(X_{1}\right)$ dan store atmosphere $\left(X_{2}\right)$ secara parsial memberikan pengaruh signifikan terhadap kepuasan pelanggan $(\mathrm{Y})$, dengan besar sumbangan pengaruhnya $38,5 \%$. Hipotesis penelitian kedua adalah ada pengaruh antara kualitas pelayanan terhadap kepuasan pelanggan. Berlandaskan rekapan hasil uji regresi berganda yang nampak di Tabel 1 menunjukan nilai koefesien korelasi kualitas pelayanan sebesar 0,278 dan p-value 0,004 < Alpha ( $\alpha$ ) 0,05, sehinga dinyatakan menolak Ho yang artinya terdapat pengaruh positif signifikan dari kualitas pelayanan $\left(\mathrm{X}_{1}\right)$ terhadap kepuasan pelanggan $(\mathrm{Y})$, dengan sumbangan pengaruh sebesar $7,7 \%$. Hipotesis penelitian ketiga adalah terdapat pengaruh dari store atmosphere ke kepuasan pelanggan. Berdasarkan rekapan hasil uji regresi berganda di Tabel 1 menunjukan nilai koefesien korelasi store atmosphere sebesar 0,377 dan $p$-value $0,000<$ Alpha ( $\alpha$ ) 0,05 , yang dinyatakan menolak Ho yang artinya adanya pengaruh secara positif signifikan dari store atmosphere $\left(\mathrm{X}_{2}\right)$ ke kepuasan pelanggan $(\mathrm{Y})$, dengan sumbangan pengaruh sebesar $14,2 \%$.

Berdasarkan hasil penelitian yang dilakukan menunjukan bahwa kualitas pelayanan dan store atmosphere berpengaruh terhadap kepuasan pelanggan KFC Singaraja. Hasil tersebut menunjukan apabila variabel kualitas pelayanan dan store atmosphere mengalami kenaikan atau penurunan secara bersama-sama maka akan berpengaruh terhadap kepuasan pelanggan. Suatu perusahaan yang mampu memberikan pelayanan yang dapat memenuhi harapan pelanggannya serta memiliki lingkungan belanja yang menyenangkan bagi pelanggan maka akan dapat memberi kepuasan dibenak pelanggan. Ketika perusahaan hanya memberikan kualitas pelayanan yang baik namun tidak didukung oleh suasana gerai yang nyaman dapat menyebabkan tingkat kepuasan pelanggan tidak optimal. Hasil dalam penelitian ini sejalan dengan penelitian Kristiana dan Edwar (2017) penelitian tersebut menyatakan store atmosphere dan kualitas layanan mempengaruhi secara parsial dan simultan ke kepuasan konsumen. Hasil penelitian lain telah dibuktikan juga oleh Nawaningsih (2017) yang mendapatkan hasil store atmosphere dan kualitas pelayanan memiliki pengaruh ke kepuasan pelanggan. Penelitian oleh Kusumawathi,dkk (2019) juga mendapatkan hasil jika store atmosphere dan kualitas layanan memberikan pengaruh yang signifikan serta memiliki nilai positif ke kepuasan konsumen.

KFC sebagai sebuah perusahaan yang bergerak dalam bidang restoran cepat saji tentunya harus dapat memperhatikan kualitas pelayanan dan store atmosphere untuk dapat meningkatkan kepuasan pelanggan. Semakin tinggi kualitas pelayanan dan store atmosphere yang diberikan, maka akan semakin tinggi pula kepuasan pelanggannya, sebaliknya ketika kualitas pelayanan dan store atmosphere yang diberikan menurun, maka akan semakin menurun juga tingkat kepuasan pelanggannya. Dalam hal meningkatkan kualitas pelayanan KFC Singaraja dapat dilakukan dengan meningkatkan layanan yang dapat memudahkan pelanggan ketika hendak membeli produk yang ditawarkan KFC. Selain memberikan pelayanan kepada pelanggan, KFC Singaraja juga harus mampu menciptakan suasana gerai yang nyaman bagi para pelanggannya.

Hasil dalam penelitian ini menunjukan bahwa kualitas pelayanan berpengaruh positif dan signifikan terhadap kepuasan pelanggan. Hal ini sesuai dengan pernyataan Dewi,dkk (2019) yang menyatakan kualitas pelayanan menjadi suatu hal yang tidak dapat dilepaskan dengan kepuasan pelanggan, karena kualitas layanan dapat memotivasi pelanggan untuk menjalin hubungan yang kuat dengan perusahaan, dan dalam jangka panjang hubungan seperti ini memungkinkan perusahaan secara cermat untuk memahami harapan dan kebutuhan pelanggan. Hasil dalam penelitian ini sejalan dengan riset yang dilakukan oleh 
Sulistyawati dan Seminari (2015) mengungkapkan bahwa variabel kualitas pelayanan berpengaruh positif dan signifikan kepada kepuasan pelanggan. Hal yang sama juga diperoleh pada penelitian Nawangsih (2017) yang menyatakan kualitas pelayanan berpengaruh positif dan signifikan terhadap kepuasan pelanggan. Penelitian oleh Kusumawathi,dkk (2019) juga menjelaskan kualitas pelayanan berpengaruh signifikan dan memiliki nilai positif terhadap kepuasan konsumen.

KFC Singaraja dalam upaya untuk meningkatkan kepuasan pelanggan tentunya harus memperhatikan pelayanan yang diberikan. Pelayanan tersebut bisa dilihat dari bagaimana cara karyawan ketika berinteraksi dengan konsumen. Sikap karyawan yang ramah, sopan dan cekatan ketika pelanggan membutuhkan sesuatu tentunya dapat membuat para pelanggan menjadi nyaman ketika berbelanja. Selain itu pelayanan tersebut bukan hanya terkait dengan interaksi karyawan yang berhadapan langsung dalam melayani pelanggan, akan tetapi juga pelayanan dapat mencangkup beberapa fasilitas yang disediakan seperti meja, kursi, wastafel, dll yang dalam kondisi baik.

Berdasarkan pengamatan yang dilakukan peneliti pada gerai KFC Singaraja yang dimana pada gerai tersebut terdapat beberapa layanan yang tidak tersedia pada gerai KFC pada umumnya. Layanan tersebut adalah layanan 24 jam dan drive thru. Layanan 24 jam tersebut merupakan salah satu fasilitas yang menjadi keunggulan dari KFC karena dapat menyasar masyarakat yang lapar di malam hari sehingga mereka tidak bingung harus membeli apa untuk mengisi perut mereka. Selain itu layanan drive thru juga tidak tersedia pada gerai KFC Singaraja, padahal layanan ini sangat memudahkan pelanggan yang ingin memesan makanan untuk dibawa pulang, sehingga mereka tidak perlu masuk ke dalam gerai dan hanya cukup memesan pada layanan drive thru tanpa harus turun dari kendaraan mereka. Oleh sebab itu pihak KFC Singaraja harus memberikan pelayanan yang optimal guna menciptakan kepuasan bagi pelanggannya. Pelayanan yang maksimal akan membuat pelanggan menjadi puas dan membuat pelanggan untuk kembali membeli produk yang ditawarkan.

Berlandaskan hasil penelitian yang dilakukan, hasil dalam penelitian ini menunjukan bahwa store atmosphere berpengaruh terhadap kepuasan pelanggan. Hal ini sesuai dengan pernyataan Putri,dkk (2014) yang menyatakan bahwa konsumen tidak hanya menanggapi suatu produk dan jasa yang disediakan, tetapi juga memberikan tanggapan terhadap lingkungan pembelian yang mampu memberikan perasaan menyenangkan bagi konsumen. Semakin terencana store atmosphere yang diciptakan oleh suatu perusahaan maka semakin tinggi juga tingkat kepuasan yang dirasakan oleh pelanggan. Sejalan dengan riset yang dilakukan oleh Kusumawathi,dkk (2019) yang menyatakan store atmosphere memiliki dampak yang positif dan signifikan ke kepuasan konsumen. Penelitian oleh Kristiana dan Edwar (2017) juga memperoleh hasil store atmosphere mempunyai pengaruh terhadap kepuasan pelanggan. Hal yang sama juga didapat dari penelitian Nawangsih (2017) yang menunjukan variabel store atmosphere terbukti memberikan pengaruh yang signifikan dan positif ke kepuasan pelanggan

KFC sebagai restoran modern tentunya harus mempunyai suasana gerai yang terencana sehingga pelanggan menjadi betah ketika sedang berada didalam gerai tersebut. Suasana gerai tersebut direncakan untuk dapat merangsang indra para pelanggan sehingga secara tidak langsung mampu mempengaruhi perilaku pembelian. Penempatan tata letak meja, kursi, wastafel dan yang lainnya tentunya harus dipikirkan dengan baik untuk memberikan ruang gerak yang nyaman bagi konsumen. Pengaturan pencahayaan yang baik dan pewarnaan yang sesuai pada sudut tertentu dapat menghidupkan suasana pada gerai sehingga dapat memberi kenyamanan bagi para pelanggan ketika sedang berada didalam gerai tersebut. Selain itu aroma dan musik yang diberikan dalam suatu ruangan juga dapat mempengaruhi selera makan konsumen sehingga konsumen memiliki suasana hati yang baik dan menghabiskan waktu yang cukup lama didalam gerai. Ketika pelanggan nyaman dengan suasana gerai yang diberikan oleh perusahaan, hal tersebut dapat membuat pelanggan merasa senang dan puas. Dari kepuasan itulah dapat menarik minat dari pelanggan untuk datang lagi dan melakukan pembelian kembali. Pengalaman belanja yang menyenangkan sesuai dengan harapan pelanggan dapat menyebabkan meningkatnya kepuasan pelanggan. 
Kualitas pelayanan dan store atmosphere memiliki peran penting dalam meningkatkan kepuasan pelanggan. Hal tersebut dikarenakan ketika pelayanan yang diberikan oleh suatu perusahaan optimal dan didukung oleh suasana gerai yang baik maka akan membuat pelanggan tersebut menjadi puas dan akan membeli kembali produk yang ditawarkan oleh perusahaan tersebut. Hal tersebut dibuktikan melalui hasil penelitian ini yang menyatakan bahwa kualitas pelayanan dan store atmosphere memiliki pengaruh yang positif dan signifikan terhadap kepuasan pelanggan. Hasil dalam penelitian ini memberikan implikasi bahwa setiap perusahaan yang ingin meningkatkan kepuasan pelanggannya harus mampu memberikan kualitas pelayanan yang maksimal dan store atmosphere yang terencana dengan baik maka akan dapat memberikan respon yang positif serta kenyamanan pada pelanggan sehingga mampu meningkatkan kepuasan pelanggan.

Hasil penelitian ini diharapkan dapat digunakan oleh pihak perusahaan dalam mengambil keputusan terkait dengan peningkatan kepuasan pelanggan melalui kualitas pelayanan dan store atmosphere. Peningkatan kualitas pelayanan dapat dilakukan dengan memberikan layanan yang ramah, cekatan dan sopan dalam melayani kebutuhan pelanggannya. Selain itu juga perusahaan harus memastikan fasilitas yang tersedia di KFC Singaraja seperti meja, kursi, wastafel, toilet, dll dalam keadaan baik. KFC Singaraja juga dapat meningkatkan pelayanan yang diberikan dengan menyediakan layanan drive thrue dan layanan 24 jam seperti gerai KFC pada umumnya serta memberikan fasilitas parkir yang nyaman bagi para pelanggannya.

KFC Singaraja juga harus merencanakan store atmosphere yang baik sehingga memberikan kenyamanan bagi pelanggannya. Hal tersebut dapat dilakukan dengan mengatur tata letak meja, kursi dan atribut lain didalam gerai KFC sehingga mampu memberikan ruang gerak yang nyaman bagi pelanggan. Selain itu juga pengaturan pencahayaan yang baik dan pewarnaan yang sesuai pada sudut tertentu dapat menghidupkan suasana pada gerai sehingga dapat memberi kenyamanan bagi para pelanggan ketika sedang berada didalam gerai tersebut. Ditambah lagi dengan adanya aroma dan musik yang disajikan dalam suatu ruangan yang dapat mempengaruhi selera makan konsumen sehingga konsumen memiliki suasana hati yang baik dan menghabiskan waktu yang lama didalam gerai.

Berdasarkan deksripsi data penelitian ini menyatakan bahwa mayoritas pelanggan KFC Singaraja berusia 17-22 tahun, yang dimana usia tersebut merupakan usia para pelajar atau mahasiswa. Kondisi itu juga dapat dimanfaatkan oleh KFC untuk memberikan suasana gerai yang nyaman bagi para pelajar dan mahasiswa untuk belajar atau sekedar mengerjakan tugas bersama pada gerai KFC. Ketika KFC mampu menciptakan store atmosphere yang menyenangkan bagi mereka tentunya hal tersebut dapat membuat mereka nyaman dalam belajar sehingga kedepannya mereka akan kembali datang ke KFC dan merekomendasikan pengalamannya tersebut kepada teman-temannya.

\section{Simpulan dan Saran}

Berlandaskan pada hasil dan pembahasan, maka disimpulkan: (1) Ada pengaruh signifikan secara simultan antara kualitas pelayanan dan store atmosphere terhadap kepuasan pelanggan KFC. Hal tersebut menunjukan bahwa jika kualitas pelayanan dan store atmosphere yang baik maka akan meningkatkan kepuasan pelanggan. (2) Ada pengaruh positif dan signifikan secara parsial antara kualitas pelayanan terhadap kepuasan pelanggan KFC. Hal tersebut menunjukan apabila kualitas pelayanan yang diberikan maksimal maka akan memenuhi harapan konsumen dan menyebabkan semakin meningkatnya kepuasan pelanggan. (3) Ada pengaruh positif signifikan secara parsial antara store atmosphere terhadap kepuasan pelanggan KFC. Hal ini menunjukan bahwa store atmosphere yang terencana mampu memberi kenyamanan kepada pelanggan sehingga meningkatkan kepuasan pelanggan.

Adapun saran bagi peneliti selanjutnya diharapkan dapat mengembangkan penelitian ini dengan menambahkan variabel-variabel lain yang dapat mempengaruhi kepuasan pelanggan, mengembangkan subjek penelitian dan dapat memperbanyak teori-teori terkait dengan variabel yang dipakai serta dapat menggunakan teknik analisis data lain yang dapat digunakan 
menjadi acuan untuk penelitian kedepannya dan meningkatkan pengetahuan khususnya dalam ilmu manajemen dalam bidang pemasaran.

Teruntuk pihak perusahaan restoran fast food khususnya KFC juga diharapkan untuk selalu mengedepankan pelayanan yang maksimal untuk dapat menambah tingkat kepuasan pada pelanggan. Selain itu pihak restoran cepat saji seperti KFC juga perlu merencanakan suasana gerai dengan baik agar mampu berikan kenyamanan sehingga konsumen menjadi betah dan mempengaruhi perilaku pembeliannya.

\section{Daftar Pustaka}

BPS Provinsi Bali. 2019. Banyaknya restoran dan rumah makan dirinci menurut Kabupaten/Kota di Bali 2012-2019. Denpasar: Badan Pusat Statistik Provinsi Bali.

Dewi, Kadek lin Listyana, Ni Nyoman Yulianthini dan N.L.W Sayang Telagawathi. 2019. "Pengaruh Dimensi Kualitas Pelayanan Terhadap Kepuasan Pelanggan Pengguna BPJS Kesehatan di Kota Singaraja". Bisma: Jurnal Manajemen, Vol.5 No.2

Ghozali, Imam. 2011. "Aplikasi Analisis Multivariate Dengan Program SPSS”. Semarang: Badan Penerbit Universitas Diponegoro.

Kompas. 2020. McDonald's, Texas Chicken, KFC, Wendy's, A\&W: Manakah Restoran Cepat Saji Pertama di Indonesia?. Diakses pada 8 November 2020, dari https://travel.kompas.com/read/2020/05/08/203800927/mcdonald-s-texas-chicken-kfcwendy-s-a-w--manakah-restoran-cepat-sajipertama?page=all\#: :text=KFC\%3A\%201970an,di\%20Jalan\%20Melawai\%20di\%20Ja karta.

Kotler, Philip dan Kevin Lane Keller. 2009. Manajemen Pemasaran. Edisi 13. Jilid 2. Alih bahasa: Bob Sabran. Jakarta : Penerbit Erlangga.

Kristiana, Maria dan Muhammad Edwar. 2017. "Pengaruh Store Atmosphere Dan Kualitas Layanan Terhadap Kepuasan Konsumen Cafe Heerlijk Gelato Perpustakaan Bank Indonesia Surabaya". Jurnal Pendidikan Tata Niaga (JPTN). Volume 01 Nomor 01.

Kusumawathi, N.W Giana, Dwi P. Darmawan dan I G.A Oka Suryawardani. 2019. "Pengaruh Store Atmosphere, Kualitas Produk, dan Kualitas Layanan terhadap Kepuasan Konsumen di Seniman Coffee Studio". E-Jurnal Agribisnis dan Agrowisata Vol. 8, No. 1.

Lutfi, Aden Winangun. 2020. Pengaruh Kualitas Pelayanan Dan Kepercayaan Nasabah Terhadap Kepuasan Nasabah Pada Lembaga Perkreditan Desa Di Kalibukbuk. Skripsi. Universitas Pendidikan Ganesha.

Mufidah, Nur Lailatul. 2012. "Pola Konsumsi Masyarakat Perkotaan”. Jurnal Unair BioKultur, Vol.1, No.2.

Mulyanto , E dan Yoestini. 2011. Analisis Pengaruh Kualitas Pelayanan Terhadap Kepuasan Pelanggan Pada Bengkel Ajisaka Motor Kudus. Undergraduate Thesis. Universitas Diponegoro

Nawangsih, Mashariono. 2017. "Pengaruh Store Atmosphere, Kualitas Layanan, Dan Lokasi Terhadap Kepuasan Pelanggan Makmu Surabaya". Jurnal IImu dan Riset Manajemen Volume 6, Nomor 11.

Pojoh, Laurina S.A., Paulus Kindangen and Fitty V. Arie. 2019. "The Influence Of Product Diversity And Store Atmosphere On Customer Satisfaction At Miniso Manado". Jurnal EMBA Vol.7 No.4.

Putri, Lily H., Srikandi Kumadji dan Andriani Kusumawati. 2014. "Pengaruh Store Atmosphere Terhadap Keputusan Pembelian Dan Kepuasan Pelanggan (Studi pada Monopoli Cafe and Resto Soekarno Hatta Malang)". Jurnal Administrasi Bisnis (JAB) Vol. 15 No. 2.

Santoso, Singgih. 2001. SPSS Versi 11,5 Mengolah Data Statistik Secara Profesional. Jakarta: PT Elex Media Komputindo. 
Sugiyono. 2017. Metode Penelitian Kuantitatif Kualitatif \& RND. Bandung: Alfabeta.

Sulistyawati, Ni Made Arie dan Ni Ketut Seminari. 2015. "Pengaruh Kualitas Pelayanan Terhadap Kepuasan Pelanggan Restoran Indus Ubud Gianyar". E-Jurnal Manajemen Unud, Vol. 4, No. 8.

Tjiptono, Fandy and Gregorius Chandra. 2011. Service, Quality \& Satisfaction Edisi 3. Yogyakarta: ANDI.

Tresiya, Dhita, Djunaidi dan Heri Subagyo. 2018. "Pengaruh Kualitas Pelayanan Dan Kenyamanaan Terhadap Kepuasan Konsumen Pada Perusahaan Jasa Ojek Online GoJek Di Kota Kediri”. JIMEK - Volume 1 Nomor 2. 